Molecular-Genetic and Cytogenetic
Diagnostics

Edited by: H.G. Klein

\title{
Regulatory approaches for genetic tests and the increase of the individualised genetic knowledge ${ }^{1)}$
}

\author{
Michael Fuchs* \\ Institute for Science and Ethics, Bonner Talweg 57, \\ D-53113 Bonn, Germany
}

\begin{abstract}
In the USA, discrimination due to genetic information is prohibited by law. The German Federal Government undertook a step with the key points for a gene diagnostics law for legal regulation. The article presents possible starting points of an adjustment in particular for predictive genetic tests. In addition, it analyses what may be implemented in Germany and the USA and asks for suitability and consistency. A further requirement of an altogether desirable law is its practicability and enforceability.
\end{abstract}

Keywords: discrimination; genetic exceptionalism; health purposes; physician proviso; predictive genetic tests; prognosis.

\section{Introduction}

The increase in genetic knowledge and the successes achieved in the research of the human genome over the past years have reached a surprising and often astonishing speed, even for the experts themselves. Even though the question as to what it is that we actually know about the human genome remains unanswered, there is no doubt that this insight and knowledge comes with a wide range of possible actions. Medicine, in particular, has expanded and transformed itself quite considerably, and even more radical changes can be expected.

Among the areas of medical application that were first opened up by the growth in genetic knowledge are the genetic tests. Such tests can be used to identify and determine relations; they can serve diagnostic purposes; and finally they can help to predict the probability of certain diseases [1]. Particularly predictive genetic tests re-

\footnotetext{
1)Original German online version at: http://www.referenceglobal.com/doi/pdf/10.1515/JLM.2008.045.

The German article was translated by Compuscript Ltd. and authorized by the author.

*Correspondence: Dr. Phil. Michael Fuchs, Institute for Science and Ethics, Bonner Talweg 57, D-53113 Bonn, Germany

Tel.: + 49 (0228) 3364-1920

Fax: + 49 (0228) 3364-1950

E-mail: fuchs@iwe.uni-bonn.de
}

present a significant expansion to the medical means with which to peer into the human body, but they have also given rise to substantial concerns. This is not only true of predictive tests that are carried out on the unborn or even prior to the implantation of the embryo, but also of predictive tests applied to newborns, children and even adults.

Such concerns revolve around the special quality of the predictive insight gained from genetic testing, the particulars of access to such insight, or the quantity of such knowledge. The explicit statement that the use of genetic tests should not be limited in any way, therefore, continues to be an exception in the worldwide debate among experts from the various disciplines involved [2, 3]. By contrast, the view that genetic knowledge is not different from other types of medical knowledge or types of knowledge generated for the sake of medicine and, therefore, does not require a separate regime has many, implicit and explicit, proponents. The legal-political debate, both at national and international levels, is impressed by the sensitivity of individual genetic knowledge and, in particular, the predictivity of genetic testing [4-8].

The Council of Europe, for example, has demanded a targeted limitation on the use of predictive genetic tests in its various documents. They have not been signed and ratified by Germany, because the opposition, which has the public's attention, has considered them to be too research-friendly and not restrictive enough. This means, of course, that at this point there is no general rule for genetic testing in Germany. This fundamental opposition against international compromises in bioethics has thus resulted in genetic testing in Germany being left out without any comprehensive rules and regulations. Special bills to be brought before the legislature have been put off time and again.

\section{Current plans for regulation}

The United States has passed a specific bill [9] and in Germany the key points for such a law have been published by the relevant governmental departments [10, 11]. The American federal law has as its objective the prevention of discrimination in the labour market and in health insurance on the basis of genetic information. Providers of health insurance especially are forbidden to 
use knowledge of a genetic predisposition to charge a healthy insured a higher premium or to deny insurance cover. Employers are prohibited from using genetic information about individuals for the purposes of hiring, firing, assignments or promotions.

The key points defined and agreed by the German federal cabinet in April 2008 also focus on the rights of individuals to defend themselves against such misuse of genetic information [10]. As provided for in the coalition agreement, the purpose is to "regulate the areas that require special protective standards in view of the advances made in human genetics in order to protect the personal rights of citizens". Similar to the approach taken by the US, narrow limits have been proposed for the labour market and insurance sector where genetic testing could be used:

"In labour law and with respect to the protection of employees and labour, the marginalisation of people due to genetic disposition is to be prevented. Labour law has to prohibit, as a matter of principle, any genetic testing ordered or demanded by employers. In addition, employers must not inquire about, obtain or use results of any other genetic tests done in a different context. Standard tests and examinations in the labour market that are used to determine the physical aptitude of candidates for specific work places or activities will continue to be permitted. Under labour protection provisions, genetic testing as part of occupational-medical precautionary examinations is not to be permitted or only to a very limited extent. Routine examinations on a voluntary basis, as have been practised so far, will continue as before for the protection of workers.

Insurance companies must not order genetic testing or demand to see results of previous genetic tests in connection with the signing of insurance contracts or policies. Any use of such test results will not be permitted even if the person concerned has volunteered such information. Exceptions are to be provided for in order to prevent abuse in special circumstances, e.g., life insurance policies with a very high amount insured" [10].

The key points pick up on the special sensitivity of genetic data and also provide for data protection aspects related to the passing on of and access to such data. The permissibility of "routine examinations as practised so far", however, will not be limited to non-genetic tests. Overall, these key points constitute an attempt at combining several ideal and typical rules and regulations.

\section{Starting points for possible regulation}

The literature on genetic testing available thus far allows for four regulatory approaches to be gleaned from it [3]:

Aspects that bear mentioning here are predictive test procedures that are made dependent on health purposes; the formulation of a physician proviso with respect to testing and consulting; the introduction of special test and approval procedures or the targeted prevention of discrimination in connection with genetic tests through political and legislative measures.

The introduction of test and approval procedures is primarily geared to technical quality checks of the test kits. By contrast, the other restrictions refer to specific risks that could be linked, also and particularly so, to a valid test.

The proposal for an anti-discrimination law or political measures to this effect, as tabled by Onora O'Neill [12] and which has found its way into the "Genetic Information Nondiscrimination Act of 2008" in the United States [9], involves primarily an assessment of the "personal proximity" of genetic information. The individual does not have to be protected from his or her own knowledge about his or her future, but from such information being obtained by others who may stigmatise the person thus tested, i.e., by holding him or her in lower esteem based on the information or by disadvantaging, that is, discriminating against him or her in an unjustifiable manner on the basis of such test results.

Unlike the concept of anti-discrimination, the proposal for a physician proviso is not primarily aimed at the potential passing on of information to a third party, but at the very collection of such information. The test can be seen either as an intervention, like a medical intervention, which is justified solely by medical practice (i.e., directed at healing or reducing a patient's suffering), or as a risk to the person tested, in view of the special nature of the data thus collected, if the information is not interpreted properly and "translated" for the life of the tested person. Such interpretation or translation is expected of a person trained in natural sciences and human genetics as well as experienced, as a physician, in the verbal conveying of possible actions to take.

In some cases, the physician proviso may be upgraded to a specialist proviso. Particularly human geneticists demand that tests should be done only by specialists of human genetics.

Another approach to regulate the collection of such data is that testing must be tied to a purpose. Tests, it is said, are only legitimate if they are tied to health-related purposes. In the way this is done by the Council of Europe, it is also primarily to prevent discrimination. For the convention on biomedicine by the Council of Europe subjects to such required purpose only such tests as are carried out in connection with a disease or serve to determine a specific carrier status. As the explanatory notes to the convention state, this is mainly about excluding certain types of uses of genetic tests in occupational medicine or for insurance purposes. A lot more essential in its basic definition is the required purpose found in current French law. Book 1, Title 1, Chapter 3 of the Code Civil contains the following wording in section 16-10: "L'examen des caractéristiques génétiques d'une personne ne peut être entrepris qu'à des fins médicales ou de recherche scientifique". Here, the linkage to health-related purposes relates to genetic testing in general. Exceptions apply only to genetic tests done for 
identification purposes, especially in the forensic field [13]. Predictive genetic tests are generally subsumed under a type of medical teleology of diagnosis, prevention and treatment, even if they are not explicitly reserved for a doctor. Here too it seems to be the intervention that requires justification through the test person's consent, which, in turn, can be achieved only through medical teleology.

The key points considered by the German federal government combine the different approaches and thus exhibit several conceptional currents. They emphasise the personal rights with reference to a person's constitutional right to self-determination in respect of information in order to prevent discrimination by statutory means. Moreover, technical quality standards are considered, to the effect that in addition to the requirement that only certified or accredited facilities and persons be admitted as testers, certain requirements ought to be set out in connection with analytical methods and their reliability. The tool of the physician proviso is to remain in effect as well. Surely this will help to shine a bit of light into an existing grey area. While the Medical Products Act, the Medical Products User Regulation, the NonMedical Practitioners Act and the Federal Data Protection Act contain specific provisions, they, overall, do not provide for the consistent and comprehensive regulation of genetic testing. In the absence of such regulation, the "Guidelines for predictive genetic diagnosis", issued by the German Chamber of Physicians, can serve as such regulation [14]. Via liability and criminal law, these guidelines can even have mandatory effects. Since they are addressed only to doctors, they cannot be seen as an ethically convincing body of regulations with respect to the general protection of personal rights. Even though the key points do not go as far as the guidelines of the medical association, that is, allowing only specialists of human genetics and doctors with the additional designation of "medical geneticist" to conduct predictive tests, there is a very clear and unambiguously defined link to the doctor, which from the point of view of legal practice probably constitutes the most significant innovation: "To guarantee the protection of persons who undergo genetic testing, genetic testing in connection with a health-related purpose shall be subject to a physician proviso. Such tests, therefore, shall be ordered only by doctors who shall have the necessary qualifications. The tests shall be carried out as per their instructions, directed under their supervision or that of a person or facility thus commissioned by them and qualified for the purpose. The result of such testing shall be communicated to the person concerned only by such doctor as has ordered the test" [10]. Overall, therefore, apart from the proposed link to health-related purposes, all regulation approaches are incorporated and combined. The recommendation to set up a "Genetic Diagnosis Commission" would provide an additional regulatory instrument.

\section{Proportionality of precautionary measures}

All this raises the question of potential over-regulation. The risk of that happening has been discussed internationally for a number of years under the heading of genetic exceptionalism [15]. According to this, genetic information is not entirely different from other medically relevant data. Even the issue of an adequate definition of genetic testing has been shaped by this debate [16]. Since genetic knowledge is created in a person's life and is medically, e.g., family history, and systematically desirable, the special treatment of genetic tests as a new procedure is inadequate, it is said. What is more, a predictive character is also found in other contexts and with other techniques.

These are important concerns that need to be taken seriously. It should be noted, in anthropological terms, that the genome does not contain what in Occidental tradition is called the soul and what could today be seen as the core of an individual's personality. A regulation that derives its justification from the nature of a certain medical product or, worse yet, from the elusive and, thus, fearsome nature of the lexeme "gene" would miss the point entirely right from the start.

\section{Prognosis and prediction}

Even the predictive nature of the knowledge, taken by itself, can be a reason to reject such knowledge on the basis of principle. Instead, it should be taken for granted that it is in people's nature to seek knowledge and that part of such quest is the desire to know about the future. In medicine such knowledge is always embedded in a context of actions. In the course of the early scientification of medicine in the Corpus Hippocraticum, too, prognosis played an important role. In fact, it is extremely crucial to identifying the proper course of treatment. Prediction can be seen as the communication of a prognosis to the patient. Such communication makes sense as a matter of principle in view of the criticism raised about the paternalistic components of the ethos of medical doctors.

Apart from prognoses grounded in natural philosophy or those confirmed as scientifically sound, the desire to know about one's own future has also triggered many practices that could be best described as being somewhere between scientific methodology, sheer speculation and charlatanry. Even as far back as in ancient times and during the Middle Ages, there was a cornucopia of known techniques. Besides dream interpretation, astrology and meteorology, one should also mention attempts to interpret the meaning of the ways in which birds fly, physiognomy and chiromancy, necromancy, geomancy, hydromancy, aeromancy and pyromancy. All these practices revolve around looking at things in such a way that they do not only signify what is already known but also come to be seen as the cause of, or a means for under- 
standing, something hitherto unknown. In his study on ethics, Thomas Aquinas reached a conclusion in the $13^{\text {th }}$ century that applied to all these practices of divination (divinatio). Inference of future contingencies, according to him, is permitted only if and when it is possible, i.e., if it leads to true insight and an actual expansion of knowledge. The moral legitimacy of the prediction thus depends on its scientific foundation, according to Aquinas. He went on to posit that it was only well-founded if the subject matter thus prognosticated was causally linked to phenomena that could be experienced directly. Such causal link between the known and that which was to be known can be direct or indirect, and it can exhibit different modalities. In cases where the effects are not necessarily determined by the known causes, one is justified only to conjecture; a definitive prediction, according to him, would exceed the boundaries of the natural ability of understanding [17]. This assessment may be astonishing, particularly if one considers its integration with the Summa theologiae, a theological overall perspective. To such extent as predictions are scientifically substantiated, they are not considered sacrilegious or presumptuous due to false curiosity.

\section{Careful handling of genetic information}

On the other hand, genetic information has characteristics that, when taken each by itself, are not exceptional but that, when combined, justify the assessment that such information is sensitive. The focus will always have to be on determining whether other information may be similarly sensitive and whether it, too, warrants regulation by reason of consistency. A statutory regulation, therefore, can very well be appropriate, and it is an appropriate regulation that seems to be called for, also for ethical reasons, in view of the rights to be protected. Even though Germany has not seen any dramatic cases in insurance law, and only few relevant cases in labour law, the risk that genetic knowledge could result in discrimination cannot be ruled out. Arguments for consistency and criticism of genetic exceptionalism do not make a cogent case against regulating genetic testing, but they can give rise to subsequent improvement in other sensitive areas of medical information.

This leaves primarily the one question as to whether the intended regulations are practical and enforceable. Are the right instruments in place to live up to the quantity of knowledge? Unlike the academic discussion, the key points do not refer to the peculiarities of chip technology at all. It must be assumed that the price for the technical provision of individual genetic information will decrease substantially. If the key points were to become law, doctors would see themselves pushed, more and more, into the role of guardians watching over personal information, with only parts of such information being medically relevant or health and disease-related. Whether such role will be appreciated and accepted, or whether people will seek out unguarded gateways to information on the internet, is something that remains to be seen.

\section{References}

1. Propping P, Arenz S, Schumacher J, Taupitz J, Guttmann J, Heinrichs B. Prädiktive genetische Testverfahren. Naturwissenschaftliche, rechtliche und ethische Aspekte. 2006;29.

2. Nozick R. Anarchy, state, and utopia. New York, 1974:315.

3. Fuchs M. Ethische Aspekte der multiparametrischen Gendiagnostik/Ethical aspects of multiparametric gene diagnosis. J Lab Med 2003:27;137-43.

4. Honnefelder L, Mieth D, Propping P, Siep L, Wiesemann C. Editors. Das genetische Wissen und die Zukunft des Menschen. Berlin, New York, 2003.

5. Heinrichs B. Prädiktive Gentests. Regelungsbedarf und Regelungsmodelle: Eine ethische Analyse. Reihe IWE Forschungsbeiträge. Bd A3. Bonn 2004.

6. Fuchs M, Lanzerath D, Schmidt M. Editoren. Prädiktive Gentests. „Health purposes“ und Indikationsstellung als Kriterien der Anwendung. The gift and the market: Cultural symbolic perspectives. Reihe IWE Forschungsbeiträge. Bd A2. Bonn 2004.

7. Nationaler Ethikrat. Prädiktive Gesundheitsinformationen bei Einstellungsuntersuchungen. Berlin, 2005.

8. Nationaler Ethikrat. Prädiktive Gesundheitsinformationen beim Abschluss von Versicherungen. Stellungnahme. Berlin, 2007.

9. An Act to prohibit discrimination on the basis of genetic information with respect to health insurance and employment. Be it enacted by the Senate and House of Representatives of the United States of America in Congress assembled, Bill number H.R. 493.

10. Bundesministerium für Gesundheit: Eckpunkte für ein Gendiagnostikgesetz, online verfügbar unter: http://www.bmg.bund. de/cln_040/nn_600110/SharedDocs/Download/DE/Presse/ Pressemitteilungen/Presse-2008/Eckpunkte-Gendiagnostik, templateld = raw, property = publicationFile.pdf/EckpunkteGendiagnostik.pdf (6. Mai 2008).

11. Richter-Kuhlmann E. Gendiagnostikgesetz. Hohe Hürden und große Lücken. Deutsches Ärzteblatt 2008;17:A855.

12. O’Neill O. Genetische Information und Nichtwissen. In: Krull W, editor. Zukunftsstreit. Weilserswist: Velbrück Wissenschaft 2000;227-42.

13. Code Civil, Buch 1, Titel 1, Kapitel 3, Art. 16-10.

14. Propping P, Arenz S, Schumacher J, Taupitz J, Guttmann J, Heinrichs B. Prädiktive genetische Testverfahren. Naturwissenschaftliche, rechtliche und ethische Aspekte. 2006;78.

15. European Commission. 25 Recommendations of the ethical, legal, and social implications of genetic testing (EUR 21120). Brüssel 2004.

16. Heinrich B. Ethische Aspekte. In: Propping P, Arenz S, Schumacher J, Taupitz J, Guttmann J. Heinrichs B. Prädiktive genetische Testverfahren. Naturwissenschaftliche, rechtliche und ethische Aspekte. 2006;115f.

17. Fuchs M. Zeichen und Wissen. Untersuchungen zum Verhältnis der Zeichentheorie zur Theorie des Wissens und der Wissenschaften im dreizehnten Jahrhundert. Münster (= Beiträge zur Geschichte der Philosophie und Theologie des Mittelalters) Neue Folge 1999;51:208. 